\title{
KAJIAN PERILAKU DAN ANALISIS KANDUNGAN GIZI PAKAN DROP IN SIAMANG (Hylobates syndactylus) DI TAMAN AGRO SATWA DAN WISATA BUMI KEDATON
}

\author{
(A STUDY ON BEHAVIOR AND ANALYSIS OF DROP IN FEED NUTRITION \\ CONTENT FOR SIAMANG (Hylobates syndactylus) IN BUMI KEDATON ZOO AND \\ TOURISM PARK)
}

\author{
Asis Tiyawati ${ }^{1}$, Sugeng P. Harianto ${ }^{1)}$, dan Yusuf Widodo ${ }^{2)}$ \\ 1) Jurusan Kehutanan Fakultas Pertanian Universitas Lampung \\ 2) Jurusan Peternakan Fakultas Pertanian Universitas Lampung \\ J1. Soemantri Brojonegoro No. 1, Bandar Lampung \\ Email: hardi_gbc@yahoo.co.id Phone: 082186388984
}

\begin{abstract}
ABSTRAK
Taman Agro Satwa dan Wisata Bumi Kedaton (TASWBK) merupakan salah satu usaha konservasi untuk menyelamatkan satwa yang terancam punah salah satunya adalah siamang (Hylobates syndactylus). Penelitian ini untuk mengetahui perilaku harian dan kandungan gizi pakan drop in siamang menggunakan metode focal animal sampling dan analisis proksimat. Pengamatan dilakukan didepan kandang satwa dan di dapur tempat penimbangan berat pakan sehingga tidak mengganggu aktivitas satwa. Hasil penelitian menunjukan bahwa perilaku harian siamang didalam kandang penangkaran didominasi oleh aktivitas lokomosi, pada jantan 43,59\% dan betina 41,18\%. Terdapat 7 jenis pakan yang diberikan dan pada 7 jenis pakan tersebut kandungan gizi yang paling tinggi adalah pisang muli. Jumlah pakan yang diberikan belum memenuhi kecukupan gizi siamang didalam kandang penangkaran.
\end{abstract}

Kata kunci : siamang, perilaku harian, pakan drop in, taman agro satwa dan wisata bumi kedaton

\section{ABSTRACT}

Bumi Kedaton Zoo and Tourism Park is an effort of natural conservation to save animals threatened of extinction, and one of those animals is siamang (Hylobates syndactylus). The objective of this research was to find out behavior and drop in feed nutrition content for siamang by using focal animal sampling method and proximate analysis. Observations were conducted before the cages and in the kitchen where the feed weighting was conducted, so that it would not disturb the animal activities. The result showed that siamang daily behavior in the cage was dominated by locomotion activities; $43.5 \%$ and $41.18 \%$ for males and females respectively. There were 7 types of feed administered to siamang and muli banana had the highest nutrition content amongst these 7 types of feeds. The nutrition necessity fulfillment for siamang in the cage was not sufficient.

Keywords : Siamang, daily behavior, drop in feed, bumi kedaton zoo and tourism park 


\section{PENDAHULUAN}

Siamang (Hylobates syndactylus) adalah kera hitam yang berlengan panjang dan hidup pada pohon-pohon. Siamang merupakan spesies terancam karena deforestasi habitatnya cepat. Satwa yang dilindungi makin banyak dimiliki perorangan secara illegal atau dengan kata lain prosedur pemeliharaannya sering tidak sesuai dengan ketentuan pemerintah. Pemerintah telah menyediakan suaka alam (kawasan tempat berlindung dan berkembang biaknya satwa liar) seperti taman nasional, suaka margasatwa dan cagar alam dengan tujuan untuk menjamin kelestarian satwa liar dari ancaman kepunahan dan memanfaatkan secara optimal.

Taman Agro Satwa dan Wisata Bumi Kedaton (TASWBK) merupakan taman wisata yang bertujuan untuk melestarikan kehidupan liar dan habitatnya di Indonesia. TASWBK yang diresmikan sejak 20 oktober 2004 yang berorientasi pada lingkungan dan pengetahuan dengan misi turut dalam upaya pelestarian satwa langka dan terancam yang mendukung pemerintah Indonesia dalam upaya penegakan hukum penertiban pemeliharaan satwa liar yang dilindungi hukum Indonesia.

Siamang (Hylobates syndactylus) merupakan salah satu satwa yang hampir punah, diselamatkan dan ditampung di TASWBK sebelum dikembalikan ke habitatnya. Siamang adalah kera hitam berlengan panjang dengan ditutupi oleh rambut yang lebat di sebagian besar tubuhnya, kecuali wajah, jari, telapak tangan, ketiak, dan telapak kaki mereka. Siamang yang lebih aktif pada siang hari mereka bersosialisasi pada kelompok-kelompok kecil yang terdiri dari dua atau tiga ekor siamang.

Pemberian pakan berupa sayur dan buah segar dengan komposisi pakan berdasarkan berat tubuh dengan kebutuhan gizi meliputi protein,lemak dan vitamin yang diperlukan setiap harinya selama dipenangkaran dibandingkan dengan kebutuhan gizi dihabitat alaminya. Tujuan dari penelitian ini juga untuk mengetahui pakan yang diberikan, nilai kandungan gizi yang ada dan aktifitas harian siamang yang ada pada TASWBK dengan manfaat dapat memberikan informasi mengenai pakan serta aktifitas harian siamang agar dapat dilakukan perbaikan dalam pengelolaannya.

\section{METODE PENELITIAN}

Penelitian ini akan dilakukan di Taman Agro Satwa dan Wisata Bumi Kedaton ( TASWBK ), Bandar Lampung. Waktu pengamatan untuk dilaksanakan pada bulan Mei 2015. Objek penelitian yaitu 2 individu siamang di TASWBK Bandar Lampung. Penelitian dilakukan selama 12 hari pada pagi pukul 08.00 WIB sampai sore hari pukul 17.00 WIB, penelitian ini dilakukan untuk mengetahui perilaku dan pakan drop in siamang.

Metode analisis data dilakukan dalam 3 metode yaitu Analisis kuantitatif, jumlah pakan per ekor per hari, dan nalisis proksimat. Analisis kuantitatif yaitu persentase nilai kejadian setiap perilaku dari keseluruhan nilai setiap perilakudengan rumus : $\mathrm{A}=\mathrm{B} / \mathrm{Cx} 100 \%$.

Jumlah pakan per ekor per hari adalah jumlah pakan Drop In yang diberikan setiap harinya akan ditimbang terlebih dahulu sebelum diberikan dan sisa pakan ditimbang kemudian dilakukan analisis proksimat, agar dapat diketahui jumlah pakan yang dikonsumsi dalam bahan kering. Besarnya konsumsi makanan total dihitung dengan rumus : Konsumsi makanan/hari $(\mathrm{kg})$ = berat pakan awal $(\mathrm{kg})$ - berat pakan sisa $(\mathrm{kg})$ (Alikodra, 1990; Susmaleni 2004).

Analisis Proksimat komposisi kandungan gizi pakan Drop In siamang dapat diketahui dengan analisis proksimat. Komposisi kandungan gizi pakan Drop In yang didapat dari masin g-masing kdar gizi setiap pakan. 


\title{
HASIL DAN PEMBAHASAN
}

\section{Perilaku Harian Siamang (Hylobates syndactylus) di Taman Agro Satwa dan Wisata Bumi Kedaton}

Siamang yang diamati pada penelitian ini berjumlah 2 ekor yaitu betina dan jantan yang sama-sama berumur 10 tahun. Siamang tersebut berasal dari BKSDA Palembang, ukuran siamang jantan lebih besar daripada ukuran siamang betina yaitu berat $25 \mathrm{~kg}$ sedangkan siamang betina memiliki berat $20 \mathrm{~kg}$.

Siamang merupakan jenis kera tidak berekor yang terbesar dibanding dengan jenis Hylobates lainnya, mempunyai kantung suara yang dipergunakan pada saat siamang bersuara serta memiliki lengan yang lebih panjang dan lebih kuat (Dixon, 1981). Siamang mempunyai badan yang berbulu hitam seluruhnya, panjang dan kelihatan seperti kusut, kecuali sekitar mulut berwarna agak keputihan (Gittin dan Raemaekers, 1980). Siamang memiliki kantung suara di bawah dagu yang dapat dipergunakan untuk resonansi suara ketika bersuara atau berteriak (Napier dan Napier, 1967).

Selama 12 hari pengamatan yang dilakukan dari pukul 08.00-17.00 dengan aktivitas makan, lokomosi, dan istirahat maka data hasil pengamatan tersebut didapatkan presentase aktivitas harian untuk jantan tertinggi adalah lokomosi 43,59\%, istirahat 34,36\% dan makan $22,05 \%$ hampr sama dengan jantan, siamang betina juga didominasi oleh aktivitas lokomosi yaitu $41,18 \%$, istirahat dan makan masing-masing $29,41 \%$. Persentase aktivitas siamang dapat dilihat pada Gambar 1.

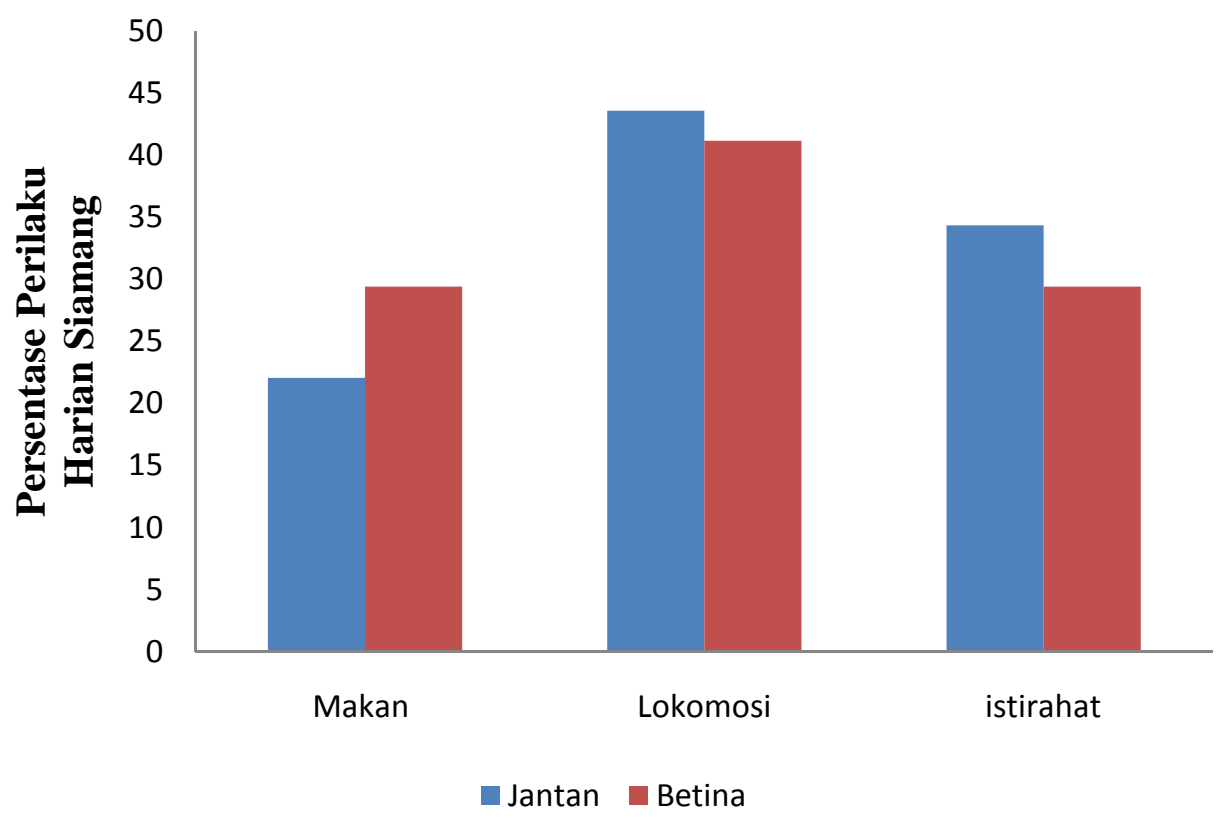

Gambar 1. Perilaku harian siamang pada Penelitian Kajian Perilaku dan Analisis Kandungan Gizi Pakan Drop In Siamang (Hylobates syndactylus) di Taman Wisata Bumi Kedaton, Mei 2015.

\begin{abstract}
Aktivitas istirahat
Pada saat istirahat siamang menghindari teriknya sinar matahari dengan cara turun ke bagian tajuk yang paling rendah. Pada periode istirahat terjadi interaksi sosial antara anggota kelompoknya melalui kegiatan berkutu-kutuan dan duduk bersama dimana jantan dewasa merupakan kegiatan pusatnya. Kegiatan istirahat akan meningkat sejalan dengan penurunan intensitas makan selama aktivitas berlangsung (Chivers, 1972).
\end{abstract}


Pada pengamatan yang dilakukan di TASWBK perilaku istirahat siamang biasanya duduk diam setelah makan dan setelah melakukan lokomosi seperti bergelayutan. Biasanya posisi istirahat siamang duduk sambil menggaruk tubuhnya sesekali dan tidur sebentar saat siang hari. Siamang betina melakukan aktivitas istirahat sebesar $29,41 \%$ sedangkan siamang jantan lebih besar yaitu $34,36 \%$ hal ini dikarenakan ukuran kandang siamang jantan yang begitu kecil sehingga hanya sedikit ruang gerak bagi siamang jantan.

Aktivitas makan

Keadaan di alam Siamang akan banyak memakan buah ketika musim buah tiba, tapi ketika tidak ada akan lebih banyak mengkonsumsi pucuk daun (Harianto, 1988). Kelompok siamang dapat melakukan kegiatan makan pada pohon yang sama untuk 2 sampai 3 hari berturut-turut dengan sesekali melakukan penjelajahan dan biasanya tidur pada pohon yang berdekatan dengan pohon sumber makanan tersebut. Lamanya kegiatan makan di suatu pohon sangat bervariasi terutama ditentukan oleh jenis dan kelimpahan makanan (Rinaldi, 1992).

Aktivitas makan pada siamang di TASWBK adalah aktivitas yang paling sedikit dilakukan dengan persentase jantan $22,05 \%$ dan betina $29,41 \%$. Pakan yang diberikan hanya pada pagi hari dengan waktu yang tidak menentu, pemberian pakan selama di kandang dilakukan oleh keeper di luar kandang. Hal ini menyebabkan pakan yang diberikan tidak sesuai dilihat dari pemberian dan jumlah jenis pakan yang diberikan.

Siamang jantan lebih menyukai pisang dan ubi tetapi siamang betina lebih menyukai pakan sayuran seperi bayam dan kangkung yang lebih dahulu dihabiskan. Agar aktivitas makan siamang di TASWBK sama seperti di alam, sebaiknya pakan drop in yang diberikan lebih awal pukul 06.00 dengan begitu sifat siamang di alam tidak begitu hilang. Perilaku makan siamang, seperti jenis primata lainnya banyak menggunakan kedua tangannya dan anggota gerak lainnya. Siamang makan dengan cara duduk di dekat keeper yang memberikan pakan.

Aktivitas lokomosi (bergerak)

Bismark (1986) mengatakan bahwa marga Hylobatidae melakukan aktivitas bergerak atau berpindah dalam kaitannya dengan pengontrolan wilayah dan aktivitas pencarian serta pemilihan pohon pakan yang kesemuanya merupakan upaya untuk memenuhi kebutuhan hidupnya serta merupakan upaya kelompok untuk menghindari predator atau bahaya. Siamang adalah satwa arboreal, oleh karena itu satwa ini sangat membutuhkan tumbuh-tumbuhan terutama pohon sebagai tempat melakukan aktivitas hariannya.

Aktivitas bergerak lebih di dominasi oleh siamang jantan dan betina . siamang lebih sering bergerak dengan bergelayutan pada besi di kandang (semi-brakiasi) tidak ada waktu khusus dimana siamang lebih banyak melakukan aktivitas bergerak dengan persentase $43,59 \%$ dan $41,18 \%$. Siamang jantan bergerak dengan bergelayutan karena kandang yang di tempatinya hanya berukuran $1,5 \times 1 \mathrm{~m}$ sedangkan pada siamng betina bergerak dan berpindah dengan leluasa karena ukuran kandang yang lebih besar hal ini menyebabkan stress pada satwa. Selain itu banyaknya pengunjung dan kebisingan yang ada disekitar kandang siamang membuat siamang lebih sering mengeluarkan suara yang membuat satwa lainnya ikut mengeluarkan suara, hal ini juga merupakan salah satu penyebab tingginya aktivitas lokomosi karena siamang merasa adanya gangguan dari aktivitas manusia.

\section{Aktivitas lainnya}

Selain aktivitas istirahat, makan dan bergerak dalam pengamatan siamang juga memiliki aktivitas lain seperti bersuara hampir disetiap kegiatannya. Akan tetapi siamang lebih sering mengeluarkan suara jika banyak pengunjung datang dan selalu bersuara setiap hari dari pukul 11.00-13.00 untuk selanjutnya istirahat. Biasanya siamang jantan lebih dahulu mengeluarkan suara lalu disusul oleh siamang betina. 


\section{Jenis dan Jumlah Pakan Drop In Siamang}

Pakan merupakan kebutuhan setiap makhluk hidup baik itu untuk tumbuhan, hewan dan manusia, karena pakan merupakan sumber energy untuuk dapat bertahan hidup dan berkembang biak. Pakan yang baik akan berpengaruh baik terhadap kesehatan satwa dan juga pada reproduksi satwa (Suharyo, 2001).

Jenis pakan yang diberikan pada siamang setiap harinya adalah pisang, ubi ungu, kacang panjang, wortel, bayam, kangkung, dan mentimun. Rata-rata jumlah pakan yang diberikan perharinya adalah $2.430 \mathrm{gr}$ dalam bahan kering. Siamang di TASWBK baik jantan maupun betina berumur 10 tahun dan memiliki berat yang berbeda, jantan $25 \mathrm{~kg}$ dan berina $20 \mathrm{~kg}$.

Tabel 1. Jenis dan jumlah konsumsi pakan siamang per hari di Taman Agro Satwa dan Wisata Bumi Kedaton Mei 2015.

\begin{tabular}{|c|c|c|c|c|c|c|}
\hline Hari & Tanggal & Jenis & $\begin{array}{l}\text { Berat awal } \\
\quad \text { (gram) }\end{array}$ & Berat sisa & $\begin{array}{c}\text { Jumlah } \\
\text { konsumsi per } \\
\text { jenis (gram) }\end{array}$ & $\begin{array}{c}\text { Jumlah konsumsi } \\
\text { per hari (gram) }\end{array}$ \\
\hline \multirow[t]{7}{*}{$\begin{array}{l}\text { Selasa- } \\
\text { sabtu }\end{array}$} & $\begin{array}{l}5 \text { mei-16 } \\
\text { mei } 2015\end{array}$ & Ubi & 450 & 0 & 450 & 2.430 \\
\hline & & Timun & 300 & 0 & 300 & \\
\hline & & Kangkung & 280 & 0 & 280 & \\
\hline & & Bayam & 240 & 0 & 240 & \\
\hline & & $\begin{array}{l}\text { Kacang } \\
\text { Panjang }\end{array}$ & 180 & 0 & 180 & \\
\hline & & Wortel & 200 & 0 & 200 & \\
\hline & & Pisang & 780 & 0 & 780 & \\
\hline
\end{tabular}

Pakan yang diberikan pada siamang oleh pihak TASWBK tidak pernah tersisa. Tetapi ada perbedaan antara siamang jantan dan siamang betina. Siamang betina lebih menyukai dedaunan karena pada saat pemberian pakan siamang betina pertama kali hanya ingin memakan dedaunan baru setelah daun nya habis siamang betina mengambil makanannya kembali seperti pisang dll. Sementara itu siamang jantan sebaliknya si jantan lebih menyukai pisang dan ubi karena pisang dan ubi yang dihabiskan terlebih dahulu sehingga apabila diberi dedaunan tidak akan diambilnya sampai pisang san ubi tersebut habis. Menurut Church (1996), hewan pada umumnya mempunyai sifat selektif terhadap pakan yang tersedia.

Pada siamang jantan palatabilitas (tingkat kesukaan) pakan dapat dilihat dari pakan pertama yang ingin dimakan satwa melihat dari bau atau aroma,bentuk, dan warna yang ada pada pakan tersebut seperti. Rangking pertama pakan yang disukai siamang jantan ialah pisang muli sementara itu siamang betina lebih menyukai sayuran atau daun yang merupakan tingkat kesukaannya. 


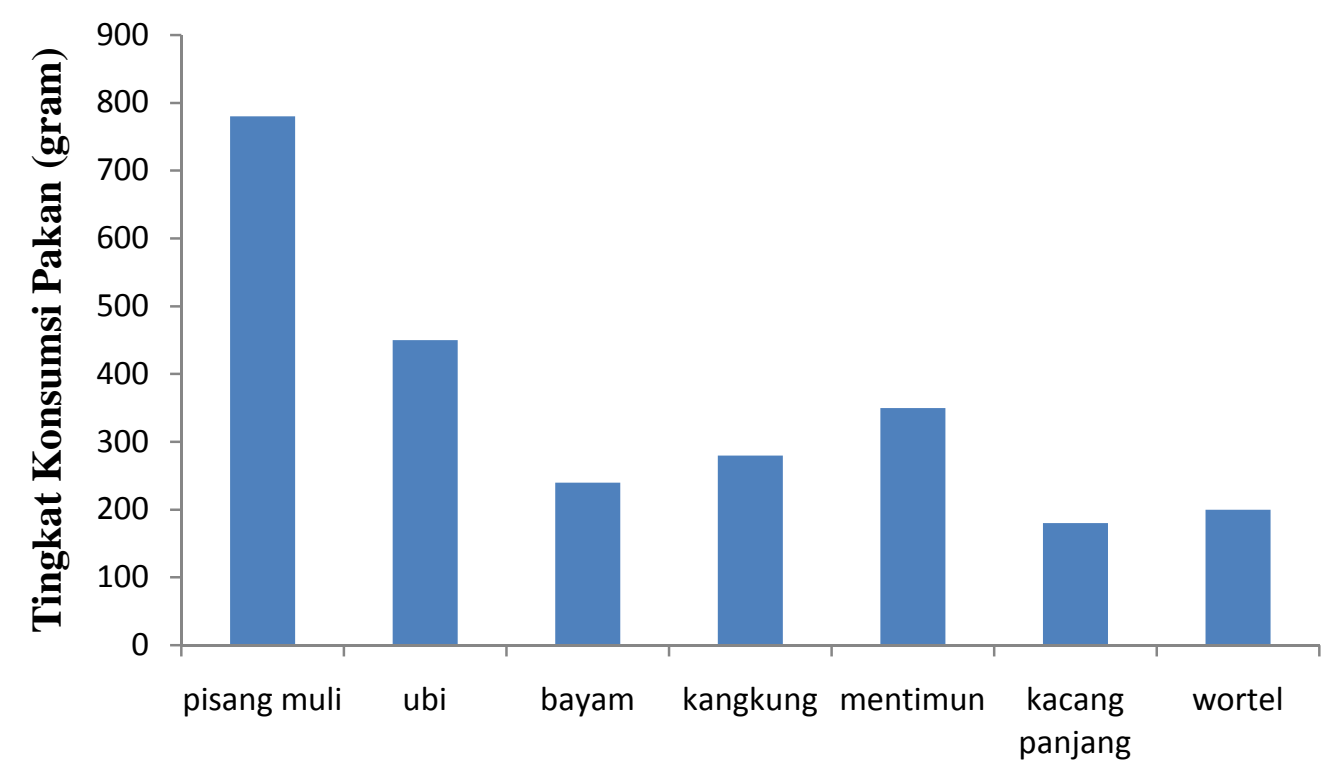

Gambar 2. Tingkat konsumsi pakan drop in siamang dalam hitungan gram pada penelitian kajian perilaku dan pakan drop in siamang di TASWBK Mei 2015.

\section{Kandungan Gizi Pada Pakan Siamang}

Kandungan gizi yang terdapat dalam pakan siamang di lakukan analisis dengan sampel masing-masing pakan dalam bobot kering. Kualitas dan kecukupan gizi didalam kandang dapat menentukan tingkat kesejahteraan dan kesehatan saat berada didalam kandang penangkaran.

Tabel 2. Hasil konversi kandungan gizi pakan drop in siamang Penelitian Kajian Perilaku dan Analisis Kandungan Gizi Pakan Drop In Siamang (Hylobates syndactylus) di Taman Wisata Bumi Kedaton, Mei 2015.

\begin{tabular}{lrrrrr}
\hline Jenis pakan & \multicolumn{2}{c}{ Tabel Kandungan Gizi Makanan Per 100 gr } \\
\cline { 2 - 6 } & \multicolumn{1}{c}{ Kadar Air } & Kadar abu & Protein & Lemak & Serat kasar \\
\hline Ubi ungu ** & 390,37 & 14,04 & 15,88 & 11,16 & 15,48 \\
Mentimun * & 342,65 & 1,05 & 0,70 & 0,70 & 1,05 \\
Kangkung * & 254,80 & 2,80 & 9,52 & 1,96 & 5,60 \\
Bayam * & 226,80 & 3,12 & 2,16 & 0,96 & 1,68 \\
Wortel * & 179,80 & 1,20 & 2,00 & 1,20 & 2,00 \\
Kacang panjang * & 21,96 & 0,72 & 31,14 & 2,70 & - \\
Pisang muli ** & 567,37 & 35,02 & 34,16 & 12,25 & 20,05 \\
\hline
\end{tabular}

Sumber: * Tabel Komposisi Pangan Indonesia 2009 (Mahmud, Hermana, Zulfianto, Rozzana, Ngadiarti, Hartati, Bernadus dan Tinexcelly, 2009)

** Hasil Analisis Proksimat di Laboratorium Nutrisi dan Makanan Ternak Universitas Lampung

Hasil penelitian yang dilakukan yaitu terdapat kandungan gizi tertinggi adalah kandungan gizi pada pisang muli. Pisang merupakan makanan pokok primata hal ini juga yang menyebabkan siamang lebih menyukai pisang . kandungan gizi yang cukup dapat memberikan keseimbangan metabolisme pada tubuh siamang yang akan diserap menjadi energi.

Pakan siamang yang memiliki kandungan gizi terbaik adalah pisang. Hal ini dapat dilihat dari total kandungan yang lebih besar dibandingkan dengan pakan yang lainnya. Pemenuhan gizi didalam kandang harus diperhatikan karena hal ini merupakan upaya 
pemeliharaan kesehatan dan kesejahteraan siamang dalam penagkaran. Pakan siamang di alam tidak sama seperti pakan yang diberikaan dalam kandang, karena siamang yang berada pada habitat alami tidak memakan sayur-sayuran dan ubi. Siamang pada habitat alami memakan daun-daun yang ada dihutan dan memakan buah pada musim yang ada. Sementara itu pakan yang diberikan belum cukup untuk memenuhi kebutuhan gizi pada siamang dikarenakan pemberian pakan dengan jumlah dan jenis yang sedikit.

\section{Ukuran kandang}

Terdapat ukuran kandang yang berbeda antara siamang jantan dan betina tetapi aktivitas mereka tidak berbeda jauh bahkan bisa dibilang sama karena lebih didominasi oleh lokomosi(bergerak) secara bergelayutan.

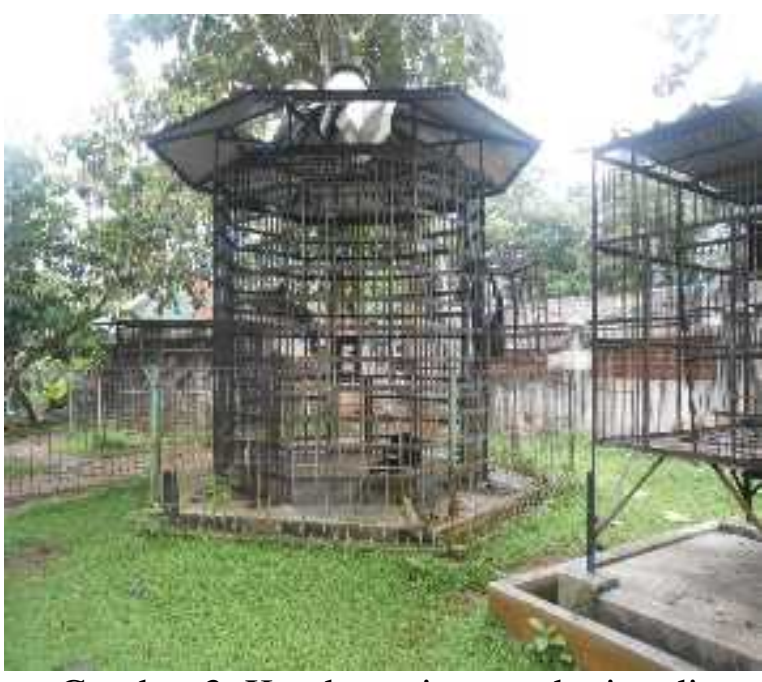

Gambar 3. Kandang siamang betina di TASWBK Mei 2015

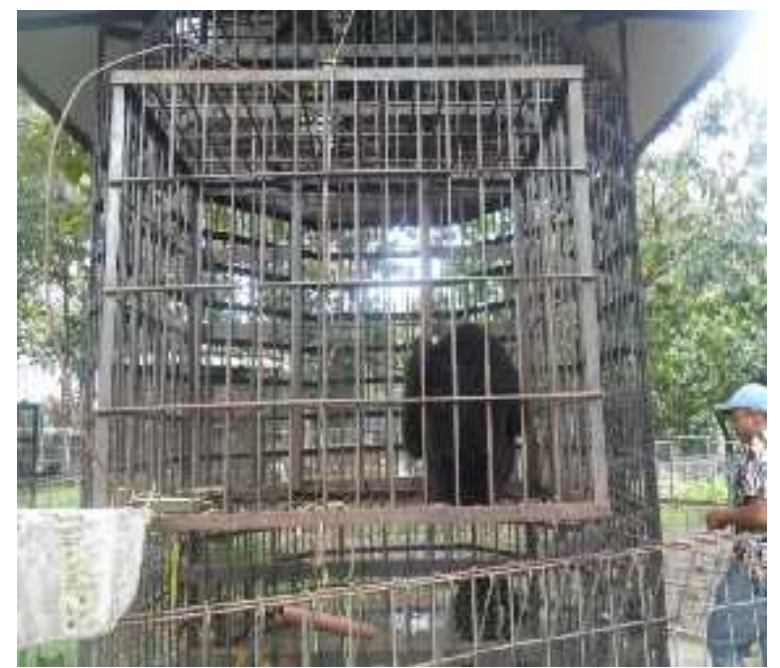

Gambar 4. Kandang siamang jantan di TASWBK Mei 2015

Kandang siamang betina memiliki tinggi 3m dan lebar 1,2m dengan 6 sisi sehingga bergerak lebih bebas dibandingkan dengan siamang jantan yang hanya memiliki ukuran lebih kecil yaitu tinggi $1 \mathrm{~m}$ dan lebar $1,5 \mathrm{~m}$.

\section{Ketersediaan dan Kesesuaian Pakan}

Berdasarkan penelitian yang dilakukan ketersediaan pakan tidak sesuai dengan habitat alaminya dalam kandang siamang juga kurang mendapatkan makanan yang cukup itupun dapat dilihat dari jumlah pakan yang diberikan untuk pengelolaan dalam kandang, ssehingga berdampak pada kesehatan dan perilaku siamang yang dapat menimbulkan stress.

Menurut Santra (2008) dalam Handbook of Zoo and Wild Animal, bahan yang dapat diberikan kepada macaca di penangkaran : nasi (125 g), sayuran (500 g), susu (250 g), irisan roti (2 iris)dan kacang tanah (100 g). jumlah makanan yang disediakan untuk hewan harus sesuai dengan ukuran tubuh, usia, jenis kelamin dan kebutuhan individu. jadwal makan macaca ekor singa di taman nasional zoologi,new delhi adalah sebagai berikut : susu $100 \mathrm{ml}$, pisang 2, mentimun $50 \mathrm{~g}$, kacang polong $100 \mathrm{~g}$, rebus kentang $100 \mathrm{~g}$, bawang $25 \mathrm{~g}$, tomat 25 $\mathrm{g}$, kacang tanah tanpa shell $50 \mathrm{~g}, 100 \mathrm{~g}$ roti, hijau jagung $100 \mathrm{~g}$ dan hijau daun $100 \mathrm{~g}$.

Pada data diatas menunjukan bahwa memang ketersediaan pakan di TASWBK yang diberikan untuk primata sejenis belum sesuai sehingga penangkaran tersebut harus memperbaiki pengelolaan satwanya seperti pemberian buah yang sudah busuk juga membeli pakan 3 hari sekali disimpan didekat kandang kuda yang dapat memberikan hama dan penyakit pada buah dan sayur tersebut sehingga dapat merusak kesehatan siamang. 


\section{KESIMPULAN}

Berdasarkan penelitian yang telah dilakukan maka dapat disimpulkan bahwa Pakan drop in siamang yang ada di TASWBK terdapat 7 jenis yaitu ubi, kangkung,bayam, kacang panjang, wortel, timun, dan pisang muli. Kandungan gizi yang terdapat pada jenis pakan drop in siamang tertinggi adalah pisang muli dan merupakan pakan yang paling banyak dikonsumsi oleh siamang per harinya yaitu 780 gram. Aktivitas harian siamang jantan hampir sama dengan betina meskipun dalam kandang yang berbeda yaitu lebih didominasi oleh lokomosi (bergerak) dengan bergelayutan dan bersuara.

\section{DAFTAR PUSTAKA}

Alikodra, HS. 2002. Pengelolaan Satwa Liar Jilid 1. Buku. Fakultas Kehutanan, Institut Pertanian Bogor. Bogor. 159p.

Bismark, M. 1984. Biologi dan Konservasi Primata di Indonesia. Buku. Program Pascasarjana, Institut Pertanian Bogor. Bogor. 230p.

Chivers, DJ and Gittins, SP. 1978. Diagnostic features of hylobatidae species. Journal of International Zoo Yearbook. 18: 57--164.

Geissman, T. 1995. Hylobatidaes systematic and species identification. Journal of International Zoo News. 42(8): 467--501.

Geissman, T., Nijman, V. and Dallmann, R. 2006. The fate of diurnal primates in southern sumatera. Hylobatidaes Journal. 2: 18--24.

Harianto, SP. 1988. Habitat dan tingkah laku siamang di calon taman nasional way kambas, lampung. Tesis. Fakultas Pascasarjana, Institut Pertanian Bogor. Bogor. 56p

Kwatrina, R. T., W. Kuswanda dan T. Setyawati. 2013. Sebaran dan kepadatan populasi siamang (Symphalangus syndactylus Raffles, 1821) di cagar alam dolok sipirok dan sekitarnya. Jurnal Penelitian Hutan dan Konservasi Alam. 10(1): 81--91.

Mahmud, M.K, Hermana, N. A. Zulfianto, R. Rozzana, I. Ngadiarti, B. Hartati, dan Bernadus. 2009. Tabel Komposisi Pangan Indonesia (TKPI). Buku. Elex Media Komputindo. Jakarta. 248.

Napier, JR and Napier, PH. 1967. A Handbook of Living Primates. Book. Academic Press. London. 567p.

Nijman V. 2004. Consevation of the javan hylobatidae hylobates moloch: population estimates, local extinctions, and conservation priorities. Journal of The Raffles Bulletin Zoology. 52(1): 271--280.

Rinaldi, D. 1992. Penggunaan metode triangle dan concentration count dalam penelitian sebaran dan populasi hylobatidae (hylobatidae). Jurnal Media Konservasi. 4(1): 9--21 .

Santra, A. J. 2008. Handbook of Wild and Zoo Animals: a Treatise for Students of Veterinary, Zoologi, Forestry and Environmental Science. International Book Distributing co. India. 480p.

Suharyo. 2001. Tehnik Penangkaran Harimau Benggala (Panthera tigris Tigris)) di Sriracha Tiger Zoo, Chonburi, Thailand dan Harimau Sumatera (Panthera tigris Sumatrae) di Taman Safari Bogor, Jawa Barat. 365p.

Susmaleni. 2004. Studi pakan drop in rusa sambar (Cervus unicolor) pasca adaptasi habitat di kandang penangkaran Universitas Lampung. Skripsi. Universitas Lampung. Lampung. 60p. 